\author{
A.K. Taussogarova* (D), S.B. Bektemirova (iD), \\ G.N. Iskakova ${ }^{(D)}$ A. Bekzhanova \\ Al-Farabi Kazakh National University, Kazakhstan, Almaty, \\ *e-mail: ayauzhan1971@gmail.com
}

\title{
FROM THE EXPERIENCE OF ETHNONYMIC HEADLINES RESEARCH
}

The elaborate treatment of the issues as the role of ethnic information as well as other information, the contexts of the use of ethnos names - ethnonyms in mass media products, the linguistic presentation of ethnic positive / negative data, their influence on consciousness of information consumers and their functions in press media of any country is considered very topical. The frequent occurrence of ethnos in various negative contexts may lead to the formation of negative associations on the ethnos in the consumer consciousness. That is why mass media is one of the mechanisms of controlling and influencing the public consciousness in positive or negative propaganda of the nation's image, the national identity, national unity processes. In this regard, the study of the headlines of press publications is being realized as they have an impact on the formation of an opinion of a reader about a definite ethnos, the emergence of an ethnic stereotype in the society in general.

Key words: ethnonymic headline, media discourse, ethnic stereotype, image of ethnos, content analysis

\author{
А.К. Таусогарова*, С.Б. Бектемирова, \\ Г.Н. Искакова, А. Бекжанова \\ Әл-Фараби атындағы Қазақ ұлттық университеті, Қазақстан, Алматы қ., \\ 'e-mail: aiauzhan@mail.ru
}

\section{ЭТНОНИМАІ ТАҚЫРЫПАТТАРАЫ ЗЕРТТЕУ ТӘЖІРИБЕСІНЕН}

Этникалық ақпараттың, сондай-ақ өзге де ақпараттың рөлі, этнонимдерді бұқаралық, ақпарат құралдарындағы этнонимдерді пайдаяану контекстері, қайсыбір этника туралы оң / теріс деректердің лингвистикалық рәсімделуі, олардың ақпарат тұтынушылардың санасына және олардың кез келген елдің бұқаралық ақпарат құралдарындағы функцияларына әсері сияқты мәселелерді пысықтау аса өзекті болып табылады. Әр түрлі жағымсыз контекстерде этнос атауының жиі көрініс табуы тұтынушы санасында этнос туралы теріс ассоциациясының қалыптасуына алып келуі мүмкін. Сондықтан да бұқаралық ақпарат құралдары ұлт бейнесін, ұлттық бірегейлікті, ұлттық бірлік процестерін оң немесе теріс насихаттауда қоғамдық сананы бақы^ау және оған ықпал ету тетіктерінің бірі болып табылады. Осыған байланысты баспа басылымдарының тақырыпаттарын зерттеу жүзеге асырылады, өйткені олар оқырманның белгілі бір этнос туралы пікірін қалыптастыруға, жалпы қоғамда этникалық, стереотиптің пайда болуына ықпал етеді.

Түйін сөздер: этнонимдік тақырыпат, медиадискурс, этникалық стереотип, этнос бейнесі, контент-та^дау.

\author{
А.К. Таусогарова* С.Б. Бектемирова, \\ Г.Н. Искакова, А. Бекжанова \\ Казахский национальный университет им. аль-Фараби, Казахстан, г. Алматы, \\ "e-mail: aiauzhan@mail.ru
}

\section{Из опыта исследования этнонимических заголовков}

Весьма актуальной представляется проработанная трактовка таких вопросов, как роль этнической информации, а также иной информации, контексты использования этнонимов этнонимов в среАствах массовой информации, мингвистическое преАставление этнических позитивных / негативных данных, их влияние на сознание потребителей инсормации и их функции в среАствах массовой информации ^юбой страны. Частое появление этноса в различных 
негативных контекстах может привести к формированию негативных ассоциаций на этнос в потребительском сознании. Именно поэтому среАства массовой информации являются одним из механизмов контроля и воздействия на общественное сознание в позитивной или негативной пропаганде образа нации, национальной идентичности, процессов национального единства. В связи с этим изучение заголовков печатных изданий активизируется, поскольку они оказывают влияние на формирование мнения читателя об определенном этносе, возникновение этнического стереотипа в обществе в целом.

Кмючевые слова: этнонимический заголовок, медиадискурс, этнический стереотип, образ этноса, контент-анализ.

\section{Introduction}

The impact of information about ethnicity published in mass media on the consciousness of mass media consumers is directly related to ethnonymic headlines. The nature of the ethnonymic headlines is defined as follows: "The use of the names of races, nationalities and nations (ethnonyms) or the derivatives composed of that ethnonym as Uzbek-Uzbekshe (Uzbek - in Uzbek), KazakhKazakhshylyk (Kazakh - peculiar to Kazakh), etc is the main features of ethnonymic headlines in mass media. In some cases it may be the name of the state or the republic, which is associated with an ethnos defined in the consciousness of people" (Karymsakova R.D. 2007: 27).

Justification of the choice of article and goals and objectives

The establishment of harmonious inter-ethnic relations in any multi-ethnic state is the most relevant in maintaining peaceful life within the country and the normal development of the country's economy. In this regard, in addition to state measures related to the development of interethnic relations, the ethnic information content reflected in mass media, including ethnonymic headlines of publication are very significant. Since the reader's attention is primarily focused on the positive or negative content of the ethnonymic headline of mass publication, it's highly possible that it can lead to the reflection of different emotions in relation to this ethnic group and formation of negative assessments. This assumption was the basis for the need to study the problem.

The purpose of the article is to determine the level of influence of ethnonymic headlines of mass publications on the consciousness of readers, the possibility of forming a positive or negative stereotype about the ethnos. In order to achieve this goal, the objectives like to select mass publications from the Kazakh mass media on an ethnonymic headlines, classify them according to various linguistic characteristics, realize an associative experiment, and a sociological survey to identify their impact on the readers' consciousness were set.
Ethnonymic headlines provide a reader with an information on the content of the publication, awaken his interest in the publication. They including evaluative and expressive meanings concerning a definite ethnos in their content, are directed to influence the consumers emotionally, and even the author may aim at convincing, inspiring confidence in his offered principles on some ethnos or people or changing their opinions and viewpoints. In this context, studying ethnonymic headlines with positive / negative content as an element mass media discourse is topical from the perspective of their impact on readers' consciousness and interethnic and intercultural communications.

The influence of mass media on the consciousness of consumers - people from the viewpoint of ideological, cultural and spiritual values system, its impact for the purpose of forming a viewpoint, opinion with the help of language tools identify its communicative and inter influential nature rather than informative one. And we think that complex communicative influence made by different strategies and verbal / nonverbal tactics between mass media products and its consumers provokes to consider it as a discourse element. T. Van Dijk defines the discourse as "a complex communicative event". The scientist identifies discourse as a communicative event from the prospective of "a communicative act, impact between a speaker, a listener or an observer in a particular time and space context", and the scientist points out its spoken / written, verbal / nonverbal forms and its realization in the communication between a doctor and a patient, the process of reading a newspaper (Van Dijk T. A. 1998).

In general, consideration of discourse as a "complex communicative event" can show it as a multi aspect phenomenon. "Communicative interaction between the speaker and the listener" is likely to begin with the moment when the headline of mass media publication is formed by its author. Communicative influence concerning the content of mass media publication, is realized in the cognitivemental aspect of coding and decoding of the semantics 
of verbal / nonverbal means, language signs from the viewpoint of interpreters. The importance of establishing communication of the headline of mass media publication with the consumers is reflected in the following opinion: "The title is the most notable part of the newspaper publication. Anticipating the text it contains a definite information on the content of the material and at the same time it has an emotional-expressive function, awaking the readers' interest. Therefore, newspaper headline represents a particular synthesis of logical and emotional ones, allowing to capture the attention of more than eighty percent of the readers" (Zhikhar L. 2005).

The first feature of the ethnonymic headlines as an element of mass media discourse is in its signed characteristic consisting of the unity of its material (form) and ideal (content) components, and in the influence of these signs on the interpreters (mass media consumers). Mass media discourse, particularly ethnonymic headlines, can be viewed according to their nature as other linguistic signs in two ways shown by the scientists: "1) visible - plan of the representatives or external representations of senses and meanings; 2) mental - plan of the interpreters or means of decoding the senses and meanings" (Rusakova O. Ph., Rusakov V.M. 2008).

It is worth naming the ethnonymic headlines in mass media "cultural codes" when they are considered as representatives that are the external representation of a meaning according to the semiotic system concepts or that present a meaning in the material form. Here, the term "cultural code" is interpreted as follows: A semotician and writer Umberto Eco prefers to use the term "cultural code" instead of the term "culture language". The concept of code implies the idea of a certain order and articulation. In this regard, representatives, Eco believes, are not at all the mirror images of real objects (referents), but act in certain ways of encoding them. For example, movie images are not the impressions of the non-film reality, but a reality that has already been conceptually filtered out, to some extent interpreted" (Rusakova O. Ph., Rusakov V.M. 2008).

In addition, the following definitions about the cultural code are provided: "Coded information in a definite form that allows identification of culture" (Ivanov A.); "Cultural codes are the set of images related to the complex of some stereotypes in the consciousness; the cultural code of the nation permits to understand the behavioral skills, the psychology of the people" (Ivanov A.).

Scientific research methodology
These features of the cultural code shown by the researchers are characterized in ethnonymic headlines on the one hand as "coded information", "a set of images associated with a complex of some stereotypes in the mind", on the other hand, culturally coded ethnonymic headlines are strategies as well as language tactics of making an impact of the author on the consumer. The author aims at realizing the strategy of influencing the reader on the issue that he / she is describing in accordance with the behavioral skills of that linguocultural society or ethnicity, the psychology of people and contradicting it. In this context, we see that the mental and cultural coded language units and the headline based on their specific syntactic construction are used as language tactics.

For example, the stereotypes of people about the concepts of striptease and celebration (in this context Kazakh toi (wedding) in the headline "Striptiz na svad'be: pochemu molchit kazahskaja pressa? (Striptease at the wedding: why is the Kazakh press silent?)" (in Russian) (Kairat Matrekov) that consists of an adjective Kazakh connected with an ethnonym and their mentality play an important role. The concept of mentality, the scientific conclusions about the reflection of ethnos or nation mentality are similar in nature: "Language performs the functions of mental structuration and categorization of reality, and in every language, mentality and mentality intersect" (Suleimenova E.D. et.al. 2008), "mentality is the "general tone" of long-term forms of behavior and opinions of individuals within groups. Mentality manifests itself in everything that a person thinks about, what and how he assesses, how he correlates life and events (Khrolenko A.T. 2009:20), "mentality as a specificity of the psychological life of people is revealed through a system of views, assessments, norms and ways of thinking, based on the available in the given society knowledge and beliefs and hierarchy of values setting together with the dominant needs and archetypes of the collective unconscious one, and therefore beliefs, ideals, inclinations, interests and other social attitudes peculiar for the members of this community" (Dubov I.G. 1993:18), "the specifics of the ways of the ethnos' reaction to the phenomena and object of the surrounding world" (Petrenko V.Ph. 1987).

In the semantics of the given ethnonymic headline the following issues as the "cultural code" including the Kazakh national mentality: the ethnic stereotype of the "Kazakh toi (celebration)" in the linguistic consciousness of the people is related with the positive images as great magnificency, 
abundance, good fortune, funny melody, etc.; striptease in the Kazakh celebration, according to the national mentality, is a strange phenomenon; the understanding of avoiding shameful, impudent, abusive behavior is formed according to the ethnic stereotype of "Muslim people, the Kazakh - Muslim child" in the Kazakhs' linguistic consciousness. The author used a rhetorical question "Why is the Kazakh press silent?" aimed to expressing an intentional protest in the second component of the headline, according to the behavioral character of the ethnos, the psychology of the population. This part of the headline carries out another function as an implicit (hidden, indirect) construction: it doesn't convey the fact that the striptease happened at the wedding of the Kazakh nation directly, but through the phrase "the Kazakh press".

The content of the comments on this article with an ethnonymic headline on the Internet site 65 info has shown the positive and negative effects of the ethnic information with such ethnonymic headline. The positive influences: positive associations of the ethnic stereotype "Kazakh feast"; positive heterostereotypes of the representatives of Kazakh people about their own nation; positive heterostereotypes of the representatives of other nations about the Kazakh feasts and Kazakh nationality. The negative influences: negative stereotypes about the feasts in Russia; negative heterostereotypes of the representatives of the Kazakh nation about the Kazakh people; switch of the positive stereotype and positive associations about "Kazakh feast" to being negative; negative heterostereotypes of the representatives of other nationalities about Kazakh nation; debates with negative content about ethnic minorities between the representatives of different ethnic groups; inter-ethnic division.

Also, it is possible to observe that the negative autostereotypes appeared in the result of the impact of the negative ethnonymic headline of the article and the negative ethnic information in its content, to some extent, contribute to an emergence of a complex of profound defect in the consciousness of the representatives of the nation about their own ethnos, a loss of confidence in their ethnos, an increase of the number of people dissatisfied with their nation.

The above mentioned facts can prove the need for scientific research related to the ethnonymic headline of mass media publications. And this determines the importance of the ethnonymic headlines in mass media as one of the verbal elements in the realization of the "communicative influence between listener and listener" in cognitive-mental aspect.
In addition, the ethnonymic headlines in mass media, depending on their positive or negative semantics, may have a positive or negative impact on "the positive image formed in the public consciousness according to the measures of achievements and values in various fields (culture, economy, politics) of a nation, the image of an ethnos considered as a reputation of various linguocultural associations and society as a whole and the image of a state identified with that ethnos.

Thus, the method of content analysis was used to determine the nature of the ethnonymic headlines as an element of "communicative influence between the speaker and the listener or the author of mass media product and consumers of that product" of mass media discourse from ethnos prospect.

\section{Results and discussion}

Content analysis, identified in scientific sources as "a method of defining and evaluating the peculiar content characteristics of the text and other sources of information, especially mass media materials" (Suleimenova E.D. et.al. 2008), is used in our research to study the associates as an indicator of the influence process of ethnonymic headlines in mass media resources on the linguistic consciousness of consumers, to process the results of the social survey conducted to determine the effect on formation of a positive or negative opinion on the ethnos, and to identify the linguistic characteristics of newspaper headlines (semantic features, combination, hidden context in headlines).

The following advantages of the method of content analysis are particularly useful for our research: "Content analysis may be considered as an additional method (for example, when analyzing open answers) in the study of the frequency (or scope) of the use of one or other semantic units in the analyzed text, in determining the effectiveness of the influence of the report, in the study of the volumuous one-type documents that are relevant to the research topic, the need for a clear and objective analysis; in the case of non-systematic materials on the subject of research; when the document language (style) is important; when it is important to prove that the document contains implicit content, in mutual review and supervision of the collected data with the help of other methods (surveys, observation and control) (Chernobrovkina E.P. 2011:125 -129.).

According to the research realization stages of the content analysis method a database of headlines with ethnonym found from the Kazakhstani Kazakh and Russian mass media of the period $2010-2017$ and 150 headlines were collected. 
According to the content the collected ethnonymic headlines were grouped due to ethnic household, political and social, behavioral peculiar to the ethnos itself (moral, humane features), cultural-historical data. Different linguistic approaches (implicit structure, use of anthroponyms with ethnic informational meaning, ethnopholisms, the state, country name) were used to select individually the ethnonymic headlines identifying the ethnos implicitly and ethnonymic headlines formed on zoomorphic methaphors.

The results of the quantitative / qualitative analysis of the data collected through the social survey conducted taking into account these specific features of the gathered headlines, are as follows:
1. $91 \%$ of respondents were Kazakhs, the other $8 \%$ were the representatives of other nationalities (Russian, Korean, Tatar, Turkish, Uzbek).

2. Age peculiarities: The number of respondents aged $18-35$ years was $70.4 \%$, while those between the ages of $36-55$ accounted for $28.4 \%$. Respondents older than 55 years $-1.2 \%$.

3 . To the question in the main part "Are you interested in newspaper headlines" $72.2 \%$ of the respondents answered "yes", 22.2\% "no" and 5.6\% "sometimes". At the same time, $88.9 \%$ of the respondents think that the content of the article can be predicted according to its headline, and $61.1 \%$ of the respondents believe the ethnonym in the headline and the content of the article usually / frequently correspond, while the rest $38.9 \%$ are of the opposite opinion.

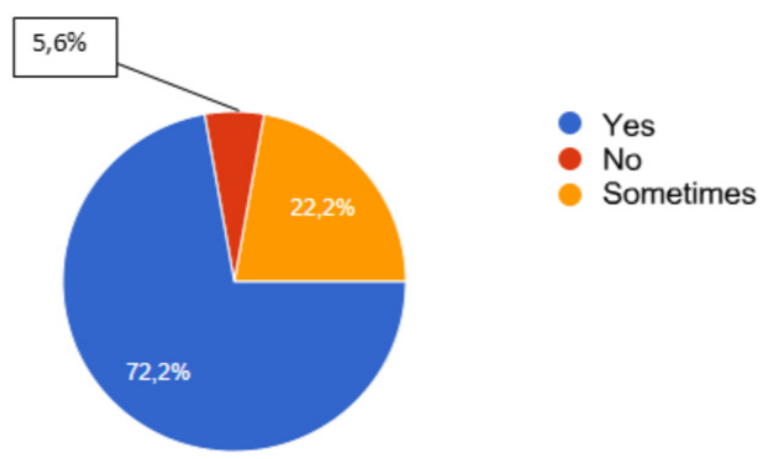

1-scheme. The percentage of the answers given to the question Does a newspaper headline attract your attention?.

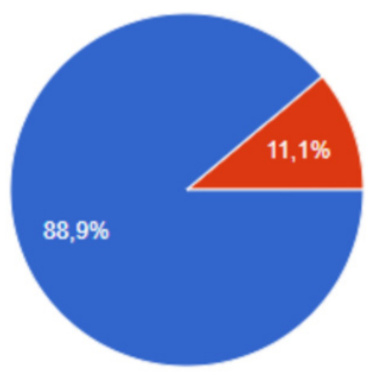

- Yes

- No

2-scheme. The percentage of the answers given to the question Can you imagine what it is about having read the headline of an article?

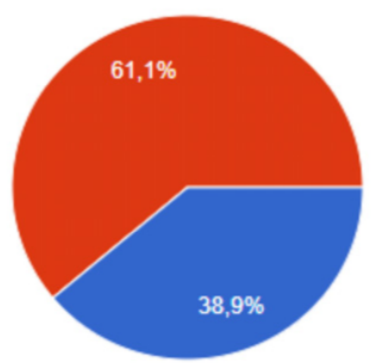

Often

Not often

3-scheme. The percentage of the answers given to the question Do you meet any texts that show a discrepancy between the headline, which includes an ethnonym (naming ethnos, nationality) and the content? 
Depending on the content of the accumulated ethnonic topics, the ethnic, political, social, ethnos were grouped according to individual behavioral (moral, moral), cultural-historical data. Ethnonic themes were identified individually by identifying the ethnos through various linguistic approaches (implicit structure, anthroponyms of ethnic information, ethnophilisms, zoomorphism metaphors, state, and country name).

According to the content the collectedethnonymic headlines were grouped according to ethnic household, political and social, behavioral peculiar to the ethnos itself (moral, humane features), culturalhistorical data. The ethnonymic headlines implicitly identifying the ethnos were individually selected by different linguistic approaches (implicit structure, use of anthroponyms with ethnic informational meaning, the positive / negative additional names of ethnoses - ethnopholisms, zoomorphic metaphors the name of a state, a country).

The answers given to the question as "How do you react to the headline "Tragedija kazahskogo mazhora: papa deneg ne daet (Tragedy of the Kazakh silver spoon: father doesn't give money)" (in Russian), "Pochemu kazahi - ohranniki? (Why are the Kazakhs security staffs?)" (in Russian), "Kazashki, tancuja pod rjep v nacional'nyh kostjumah, vzorvali kaznet (The Kazakh girls broke the kaznet, dancing to rap music in national costumes) (in Russian)" that was asked to define the impact of ethnonymic headlines about ethnic household negative issues on readers showed the following percentage.

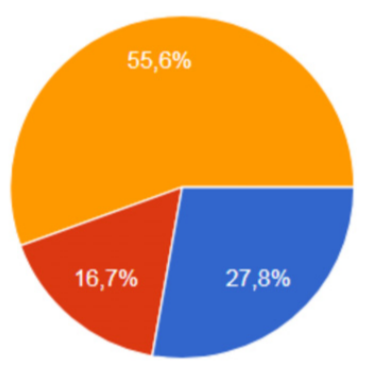

I think negatively of this ethnos

I don't react at all

I think that this is a manipulative approach (intentionally used for a negative attitude to the ethnos)

4-scheme. The percentage of the impact of ethnonymic headlines about ethnic household negative issues on readers.

The answers to the question as "How do you react to the headline "Kazahi ne umejut rabotat' vpechatlenija kitajskih turistov (The Kazakhs do not know how to work - the impressions of Chinese tourists)(In Russian)", "Zhojtterislam куndylyкtaryn кyrtuga kiristi (The Jewish people began to destroy Islamic values) (In Kazakh)", "Senator Sultanov zajavil, chto u kazahov ne bylo svoego gosudarstva
(The senator Sultanov declared that the Kazakhs had never had their own government) (In Russian)", "Pervyj russkij terrorist: neudachnik, izmenivshij istoriju (The first Russian terrorist: a failure who changed the history) (In Russian)" that was asked to define the impact of negative ethnonymic headlines with political, religious, historical content showed the following percentage (Diagram 5):

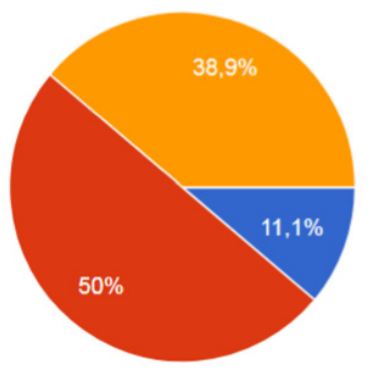

I think negatively of this ethnos

I don't react at all

I think that this is a manipulative approach (intentionally used for a negative attitude to the ethnos)

5-scheme. The percentage of the impact of negative ethnonymic headlines with political, religious, historical content on readers. 
The answers given to the questions "What do you think, what country (what countries) or about what ethnic group (what ethnic groups) these headlines are about? "Aju ormannan akyryp shykty (The bear crawled out of the forest) (In Kazakh)", "Tabeti artkan ajdahar eli (The country of dragons that has a great appetite) (in Kazakh)" and etc. that was asked to define what the readers' identification of the ethnos or state is when they read the headlines including the zoomorphic metaphors, anthroponyms, ethnopholisms, state, country names that mean implicitly ethnos or state can be seen in the Table 1 below.

Table 1. The reactions of the respondents to the question "What do you think what country (what countries) or what ethnic group (what ethnic groups) these headings are about?"

\begin{tabular}{|l|l|}
\hline \multicolumn{1}{|c|}{ Headlines } & \multicolumn{1}{|c|}{ The respondents' reactions of association with an ethnos or state } \\
\hline $\begin{array}{l}\text { “ Aju ormannan akyryp shykty (The bear } \\
\text { crawled out of the forest) (In Kazakh)” }\end{array}$ & Russia (10), Russian people, in Russian, russia or china, Rus, about Russians \\
\hline $\begin{array}{l}\text { Tabeti artkan ajdahar eli (The country of } \\
\text { dragons that has a great appetite) (in Kazakh)”, } \\
\text { «Alyp «ajdahar» shynymen azhal kusha ma? } \\
\text { (Will the «dragon» really die?) (in Kazakh) }\end{array}$ & $\begin{array}{l}\text { China (14), China. «The country of dead dragon» and «the country of insect eaters } \\
\text { «thout the Chines, Vietnam and Russia }\end{array}$ \\
\hline $\begin{array}{l}\text { "Kedendik odak: Aju, ajudyng konzhygy zhane } \\
\text { koj (Customs union: Bear, bear's cub and } \\
\text { sheep) (in Kazakh)” }\end{array}$ & $\begin{array}{l}\text { Bear: Russia/RF (12), great; } \\
\text { Bear's cub: Belarus/ Belorussia (7), Ukraine (2), a bit smaller country } \\
\text { Sheep: Kazakhstan/ the Kazakhs (8), the providing country, an ethnic minority }\end{array}$ \\
\hline $\begin{array}{l}\text { «Itke torden tosek salatyndar (The ones who } \\
\text { make a bed for a dog on the place of honour) } \\
\text { (in Kazakh)» }\end{array}$ & $\begin{array}{l}\text { Russia (the Russians), English, Russian, Europe, the Koreans, Kazakhstan-the } \\
\text { Kazakhs, Kyrgyzstan }\end{array}$ \\
\hline $\begin{array}{l}\text { «Aga dosym - Lju Chan (My older friend is Liu } \\
\text { Chan) (in Kazakh)»? }\end{array}$ & $\begin{array}{l}\text { Korean (3), Korean, Kazakhstan border with China, PRC, China/ the Chinese/ } \\
\text { about Chinese (9), China or Korean, I don't know }\end{array}$ \\
\hline
\end{tabular}

$38 \%$ of respondents said «I do not know, it's difficult to answer» the ethnopholism Jewish in the headline "Zhojtter islam куndylyкtaryn кyrtuga kiristi (The Jewish people began to destroy Islamic values) (In Kazakh)", while 22\% found it to be the nation Jewish.

Table 2. Associations and Ethnic stereotypes of the respondents caused by the influence of negative ethnonymic headlines:

\begin{tabular}{|l|l|}
\hline Kazakh (Kazakhstan) & $\begin{array}{l}\text { Lazy, not modern, is behind technology, degradation, nomadism, khanate territory, irresponsibility, } \\
\text { stubborn people, conservative, low level of Kazakhstani press, ill-mannered, impudent, Corruption, } \\
\text { unemployment }\end{array}$ \\
\hline China & $\begin{array}{l}\text { A global player, a powerful country, an invader of foreign lands, dangerous country, work dorks, country } \\
\text { of insect eaters, hordes of people, implicit policy, downloading someone's product, non-combat capture }\end{array}$ \\
\hline Russian (Russia) & $\begin{array}{l}\text { revolution, Russian terror, repression, suicide muderer-insane, provocation, chauvinistic country, bald } \\
\text { heads, skinhead, pride, aggression rebel, Power (3), strength, lazy alcohol, dominant nation, }\end{array}$ \\
\hline Kyrgyz (Kyrgyzstan) & Self-consequent Kyrgyz, the one who doesn't understand the good \\
\hline Uzbeks (Uzbekistan) & low level of tourism development, deceitful, danger, pity \\
\hline
\end{tabular}

The following questions were asked to define the reactions of the respondents occurred when they read the headlines meaning implicitly an ethnos and country using the zoomorphic metaphors, anthroponyms, ethnopholisms, the names of the country and state: What association and ethnic ste- reotypes do you have of these ethnoses when you read the headlines "Tabeti artkan ajdahar eli (The country of dragons that has a great appetite) (in Kazakh)", "Alyp «ajdahar» shynymen azhal kusha ma? (Will the "dragon" really die?) (in Kazakh)" etc.?. 
Table 3. The associations occurred under the influence of the headlines meaning implicitly an ethnos and country using the zoomorphic metaphors, anthroponyms, ethnopholisms:

\begin{tabular}{|l|l|}
\hline $\begin{array}{l}\text { The headlines with zoomorphic metaphors, } \\
\text { anthroponyms, ethnopholisms }\end{array}$ & \multicolumn{1}{|c|}{ Respondents' associations } \\
\hline $\begin{array}{l}\text { "Tabeti artkan ajdahar eli (The country } \\
\text { of dragons that has a great appetite) (in } \\
\text { Kazakh)", "Alyp «ajdahar» shynymen azhal } \\
\text { kusha ma? (Will the «dragon» really die?) (in } \\
\text { Kazakh)" }\end{array}$ & $\begin{array}{l}\text { red flag, lights, snake, invincible, hordes of people, a large strong country, a rapid } \\
\text { growth rate of the Chinese population, Chinese traditions and style, a powerful } \\
\text { country, to seize other people's lands, an angry country, a dangerous country, } \\
\text { cunning Chinese people }\end{array}$ \\
\hline $\begin{array}{l}\text { "Kedendik odak: Aju, ajudyng konzhygy } \\
\text { zhane koj (Customs union: Bear, bear's cub } \\
\text { and sheep) (in Kazakh)" }\end{array}$ & $\begin{array}{l}\text { Bear - this is power, this is Russian strong people, naïve, powerful, dominant, } \\
\text { aggression, dangerous; } \\
\text { Bear's cub - this is youth, naïve as a bear; } \\
\text { Sheep - this is crowd, sheep - the Kazakhs, kind and quite, timid }\end{array}$ \\
\hline
\end{tabular}

As it's shown in the diagrams above, the fact that the headlines of the newspaper publications can draw the attention of the reader, and the significance of its headline in determining the content of the publication can be concluded according to the percentage increase. The answers of the questionnaire show that the ethnonymic headline doesn't coincide with its content. We think that this latter case will take place as a manipulative approach to the reader.

According to the survey responses, in most cases the respondents identified the ethnos and the country that belongs to that ethnos implicitly given by zoomorphic metaphors, anthroponyms, ethnophilisms correctly and it shows the stability of ethnic stereotypes in the linguistic consciousness of the readers. Also, we can see that in the consciousness of the author of the publication and the Kazakhstani readers the images of different countries are coded by zoomorphisms. Here, the dragon associating China, in the linguistic consciousness of the readers, is decoded as the danger spreading its poison, the bear's cub expressing Belarus and Ukraine as naivety, the bear associated with Russia as aggression, the association of sheep related with Kazakhstan as meekness.

\section{Conclusion}

The results of the survey show that ethnonymic headlines in mass media draw the attention of a reader at once and have an impact on the emergence of the first positive or negative associations and ethnic stereotypes about an ethnos according to their semantics. The negative semantics included in the content of the ethnonymic headlines, as well as the inappropriate (incorrect) use of ethnonyms (ethnos, nation names) in the headline of an artcile describing some negative events, firstly, influence the formation of the negative ethnic stereotypes and associations in the linguistic consciousness of the readers about an ethnicity or the country (state) corresponded with that ethnicity. Secondly, it impacts the disharmony of interethnic or intercultural communication. Thirdly, it affects negatively the formation of the image of an ethnos or or the country (state) identified with that ethnos., fourthly, it causes the cases when the representatives of an ethnos are embarrassed about identifying themselves with their own ethnos. This, in its turn, can be said to endanger the solidarity, that is the uniqueness and unity.

\section{Әдебиеттер}

Карымсакова Р.Д. Этническая информация в СМИ // Политкорректность в СМИ Казахстана: поиск гармонии. - Алматы: «Әділ сөз», 2007. - 456 с. 27, 28-беттер.

Ван Дейк Т. А. (1998). К определению дискурса. [WWW-документ] URL http://psyberlink.flogiston.ru/internet/bits/vandijk2.htm].

Жихарь Л. Заголовок в газете // Коммуникация в современном мире: Материалы Всероссийской научно-практической конференции аспирантов и студентов «Журналистика, реклама и связи с общественностью: новые подходы», 31 октября - 1 ноября 2005 г.

Русакова О.Ф., Русаков В.М. Семиотические концепции дискурса // Русакова О.Ф., Русаков В.М. PR-Дискурс: Теоретико-методологический анализ. - Екатеринбург: УрО РАН, Институт международных связей, 2008. - 340 с.

Иванов А. Герб как культурный код // Семиотический цикл или Знаки в жизни влюблённой женщины. - Воронеж: Ассоциация историков ВГУ. http://vrn-id.ru/rassuzhdenia_o_kodax.htm 
Иванов А. Рассуждения о модернизации культурных кодов. - Воронеж:Ассоциация историков ВГУ. http://vrn-id.ru/ rassuzhdenia_o_kodax.htm

Сүлейменова Э.Д. ж.б. Әлеуметтік лингвистика терминдерінің сөздігі. Словарь социолингвистических терминов / Шәймерденова Н.Ж., Смағұлова Ж.С., Ақанова Д.Х. - Астана: «Арман-ПВ» баспасы, 2008. - 392 б.

Хроленко А.Т. Основы лингвокультурологии: учеб. пособие. - М.: Флинта, 2009. - С. 20-21.

Дубов И.Г. Феномен менталитета: психологический // Вопросы психологии. - М., 1993. - № 5. - С. 20-29.

Петренко В. Ф. Психосемантический подход к этнопсихологическим исследованиям // Советская этнография. - М., 1987. - № 4. - С. $15,19$.

Чернобровкина Е.П. Контент-анализ в лингвистических исследованиях // Вестник Бурятского госуниверситета. №11, 2011. - C. $125-129$.

\section{References}

Karymsakova R.D. Ethnic information in mass media // Political correctness in mass media of Kazakhstan: search for harmony. - Almaty: «Adil soz», 2007. - 456 p. PP. 27, 28.

Van Dijk T. A. (1998). To the definition of discourse. [WWW-документ] URL http://psyberlink.flogiston.ru/internet/bits/vandi$\mathrm{jk} 2 . \mathrm{htm}]$.

Zhikhar L. Headline in a newspaper /Communication in the modern world: Materials of the All-Russian Scientific and Practical Conference of Post-Graduate Students and Students "Journalism, Advertisement and Public Relations: New Approaches" October 31 - November 1, 2005.

Rusakova O. Ph., Rusakov V.M. Semiotic concepts of discourse // Rusakova O. Ph., Rusakov V.M. PR-Discourse: Theoretical and methodological analysis. - Ekaterinburg: UrB RAS, Institute of international relations, 2008. - 340 p.

Ivanov A. Emblem as a cultural code // Semiotic cycle or Signs in the life of a woman in love. - Voronezh: Association of Historians of VSU. http://vrn-id.ru/rassuzhdenia_o_kodax.htm

Ivanov A. Discussions on the modernization of cultural codes. Voronezh: Association of Historians of VSU. http://vrn-id.ru/ rassuzhdenia_o_kodax.htm

Suleimenova E.D. et.al. The dictionary of Sociolinguistics terms. / Shaimerdenova N.Zh., Smagulova Zh.S., Akanova D.Kh. Astana: publishing house «Arman-PV», 2008. - 392 p.

Khrolenko A.T. The basis of linguocultural studies // Textbook. - M.: Flinta, 2009. - P. 20-21.

Dubov I.G. Phenomenon of mentality: psychological // Issues of psychology. - M., 1993. - № 5 - - P. 20-29.

Petrenko V.Ph. Psychosemantic approach to ethnopsychological research // Soviet ethnography. - M., 1987. - № 4. - P. 15, 19.

Chernobrovkina E.P. Content analysis in linguistic research // Bulletin of the Buryat State University. №11, 2011. - P. 125- 129. 